Marcin Jarząbek

[Kraków]

$\bullet \bullet \bullet \bullet \bullet \bullet$

\title{
It is good to ask good questions - posing questions in oral history interview as a theoretical problem
}

Wrocławski Rocznik

According to Diogenes Laertius, students of Pythagoras "for five whole years [...] had to keep silence, merely listening to his [Pythagoras' - M.J.] discourses without seeing him, until they passed an examination, and thenceforward they were admitted to his house and allowed to see him"1. Polish philosopher Józef Tischner explained in his The Highlander's History of Philosophy (Historia filozofii po góralsku² "why [they learned] listening?" The answer was: "in order not to ask stupid questions". Than he added that the examination in the Pythagoras' school consisted in asking only one good question: "who asked well, could stay in the school, who asked wrongly, had to go away".

Today students of oral history do not have to pass such a harsh and long training like disciples of Pythagoras, but the message from the ancient Greece about listening and about good question is still valid. Oral history

1 Diogenes Laertius, Lives of Eminent Philosophers, ed. by R. D. Hicks, http://www.perseus.tufts.edu/hopper/text?doc=urn:cts:greekLit:tlgooo4.tlgoo1.perseus-eng1:8.1 (accessed November 25, 2015).

2 The term "Góral" is virtually untranslatable.

3 J. Tischner, Historia filozofii po góralsku, Kraków 1997, p. 15. 
is about listening and asking questions ${ }^{4}$; more precisely, about two kinds of questions: research question and interview question. However, while running oral history projects we rather prefer to talk about the former than the latter. Or, in worst case, we mix both together. Posing questions to an interviewee is commonly considered rather a technical, practical skill of an oral historian ${ }^{5}$ than a central methodological and theoretical problem of the whole discipline. Textbooks and Internet are full of advices how to ask questions $^{6}$ but not necessarily why to ask them. In my paper I aim at presenting functions of questioning in oral history, not only during the interview itself, but also in the phase of analysis and interpretation. I underline the fact that formulating questions during the interview is not only a matter of language and gaining information, but also of the whole course of the discussion, emotions, atmosphere etc.

There are probably many reasons why the role of questions in oral history is rather underestimated. One of them has a lot to do with the perspective from which history (and we, historians) look at that discipline? An interview for a historian is first and foremost a historical source. What matters and what is valuable, it is informative content of somebody's answers that we (historians, sociologist, memory researchers etc.) can analyze and interpret. All kinds of historical facts, experiences and their interpretations, forms of individual and collective memory are accessible in that what an interviewee is talking about. Questions' role is just to "evoke" them $^{8}$. Oral historian is rather fully aware of the subjectivity of the life

4 I paraphrase here the sentence by V. Ritchie that "oral history is about asking questions", see: D. Ritchie, Doing Oral History. A practical guide, second edition, Oxford 2002, p. 46.

5 Pragmatics of posing questions is therefore well covered in various textbooks of oral history, see: D. Ritchie, op. cit., p. 90-107; V. R. Yow, Recording Oral History. A guide for the Humanities and Social Sciences, second edition, Walnut Creek 2005, p. 74-79.

6 See: M. Hunt, The Smithsonian Folklife and Oral History Interviewing Guide, Washington 2003. http://www.folklife.si.edu/resources/pdf/InterviewingGuide.pdf (accessed November 20, 2015); in Polish: Historia mówiona. Elementarz, Warszawa 2008 (also: http://swiadkowiehistorii.pl/elementarz.php, accessed December 1, 2015).

7 Here I limit myself to historiography only, in which that problem is probably most visible. However that problem in my opinion is not limited only to the historiography.

8 The same problem we may see in the case of looking for the "linguistic picture of the world" in oral history: that very valuable analysis focuses, however, predominantly 
story interview and of the fact that time passing deeply influences memoirs. Nevertheless, he or she would still hardly ever consider his or her own questions as an inseparable part of the same source material as stories told by an interviewee. Alessandro Portelli's conclusion that oral historian in some sense is a "part of the source" ${ }^{9}$ is in my opinion in this respect still not implied into oral history research practice.

That is probably one of the reasons why in some print (or online) editions of the transcribed versions of the interview, especially in Poland, there are no questions at all. In those cases editors and/or editorial requirements tend to present dialogue as a more or less coherent monologue ${ }^{10}$. Interviewer - contrary to the remark of Portelli - seems to be a fully transparent part of the recording of the memoirs of an interviewee. That may go together with another motive for hiding questions: through them historians bare themselves and reveal their methodological proficiency with all its professionalism and in some cases - a lack of it. If we often conclude that our interviewees do not like to see their talk transcribed (to see written how they talk), we must also honestly admit that oral historians dislike it too.

\section{Functions of questioning in oral history, or: what do I ask questions for?}

Questions are, however, a key to the successful interview and also to the successful research project. Paul Thompson noticed that "a broader study of social change [...] demands particularly careful preparation of the form of questions before interviewing. Asking questions in the best way is clearly

on what an interviewee says. See: J. Bartmiński, Jezykowe podstawy obrazu świata, Lublin 2006; Historia mówiona w świetle etnolingwistyki, ed. by S. Niebrzegowska-Bartmińska, S. Wasiuta, Lublin 2008 (also: http://biblioteka.teatrnn.pl/dlibra/Content/43855/Historia_mowiona_Etnolingw.pdf, accessed December 1, 2015).

9 A. Portelli, What Makes Oral History Different (originally published as: The Peculiarities of Oral History, "History Workshop", No. 12 (1981), p. 96-107), [in:] The Oral History Reader, ed. by R. Perks, T. Alistair, London 1998, p. 73.

10 That practice is in a sense a turn back into the initial phase of oral history. Donald A. Ritchie noticed that "in the type of oral history Allan Nevins pioneered at Columbia, the interviewer was envisioned as a neutral, objective collector of other people's reminiscences; this concept was carried to such extremes that the questions were eliminated entirely in Columbia's early transcripts. The interviewee's responses were rendered as an uninterrupted narrative.", D. A. Ritchie, op. cit., p. 28. 
important in any interview"11. It does not mean only, that we must have a list of good questions already prepared when we go to talk to an interviewee. There is a need to connect our research project aims and research questions with our strategy and tactic of conducting an interview. "Even if you are going to carry only a small oral history project of your own, it is worth thinking about the sequence of topics for the interviews and phrasing the questions. The strategy of the interview it is not the informant's responsibility, but yours. It is much easier to guide if you have a basic shape already in your mind, and questions can lead naturally from one to the other"12 stated Thompson.

Question is one of really few tools that we can use during an interview and the one that plays many roles at the same time. Lynn Adams pointed four main functions of questions during an interview. "Oral historian, broadly speaking, asks people questions to discover four things: what happened, how they felt about it, how they recall it, and what wider public memory they draw upon"13. That list, however, does not include in my opinion all functions of questioning. Before going deeper into four above mentioned roles I propose to add to the list three more functions. Oral historians ask questions: (1) to keep up the communication act (dialogue, interaction), (2) to build social tie (trust) between interlocutors and (3) to accelerate process of recalling memoirs of the narrator. If the four functions proposed by Adams may be called informative (through questions we are receiving some information of various kind), the three other I would call interactive functions of questions in oral history (their focus is not on the content of the dialogue, but on the dialogue itself). Nevertheless, in practice of interviewing some questions can in fact fit into both categories of that typology (informative and interactive functions). Obviously questions "what happened" function at the same time as informative and conducting interaction, but we are not always fully aware of its double nature.

Let me focus here on the three latter, i.e. interactive functions. Maintaining the dialogue is the most basic and at the same time the most fundamental skill of any oral historian. Even in life stories methodology or in Fritz Schütze's narrative interview, where the role of questioning is predefined

\footnotetext{
11 P. Thompson, The Voice of the Past. Oral History, Oxford 1978, p. 167-168.

12 Ibidem, p. 171.

13 L. Adams, Oral History Theory, London-New York 2010, p. 78.
} 
and precisely limited ${ }^{14}$, we cannot just let the interview run without our attention. Questions, but also gestures, paraphrases, anecdotes or semi-verbal expressions are all good to subtly push the talk forward. If we agree that oral history interview should be similar to any normal natural talk between two people, than we can see that there is a place both for exchange of questions and answers, and moments of silence too. In some cases we are allowed to asked questions about the information that we already know in order to build trust and sense of self-confidence of an interviewee or to enliven the interaction. Paraphrasing has sometimes similar function too.

Good questions (i.e. well formulated and fitting into the Weltanschauung of an interviewee) are also the best tool to get a good interpersonal contact. Some of the people whom we record act very similar to the examiners in the Pythagoras' school: they judge us by our questions and they are much eager to answer the good ones than those that are wrong. They do not have to be necessarily and exclusively "easy" for our interlocutors. Even personally uneasy, but apt questions may increase trust and involvement of an interviewee. When an interviewee says: "It's a good question. I've never before thought about it from that perspective", oral historian may treat that kind of sentences as a form of real compliment. In general, "interviewers must be prepared to ask questions about painful and embarrassing subjects - although they must also respect people's right not to answer such questions, if they so choose"15.

Helping with recalling memoirs means to transform our theoretical knowledge on how human memory works into practice ${ }^{16}$. Therefore it is probably the most "technical" side of posing questions, in which interviewer should have some pre-prepared sentences and solutions (like using artefacts or photography in order to evoke memoirs, asking about specific episodes, asking interviewee to draw something etc.). Good question can "extract" memories from deep oblivion.

"Acceleration" of recalling memories and all four functions pointed by Adams have to do with various strategies of questioning (see: below).

14 F. Schütze, Biographieforschung und narratives Interview, "Neue Praxis", Vol. 13 (1983), No. 3, p. 283-293. See also (in Polish): Metoda biograficzna w socjologii, ed. by K. Kaźmierska, Kraków 2012.

15 D. A. Ritchie, op. cit., p. 36.

16 See: D. Draaisma, The Nostalgia Factory. Memory, time and ageing, New Heaven 2013 . 
I might be wrong, but I suppose that at least some of the methodological problems with interpretation of the oral history narratives as mixing together history (what happened and "how people felt about it") and memory ("how they recall it and what wider public memory they draw upon"), is due to the fact that our questionnaires do not reflect that functional distinction. We all know that in oral history it is memory (present) that influences history (past); we also agree that oral history is not only subjective (like all other sources), but also "subjectivity is all oral history is"17. Hardly ever, however, we admit that people we talk with are also self-reflective and in many cases aware of their subjectivity too. Therefore in our questions we can put an emphasis on different dimensions of somebody's recollections and at least partially rely on his or her self-reflectivity. Let me cite here one practical example: We can simply ask somebody to recall how he or she felt or thought about something in the past (then) and next ask if he or she changed his or her mind (meanwhile and now) ${ }^{18}$. This does not absolve us from critical analysis and evaluation of both answers, yet it gives us personal (subjective) interviewee's point of view on the tension between memory and history in own self-narratives.

\section{Strategies of questioning, or, what can I ask about?}

Having in mind an obvious fact that our recollections from the past are mediated through our memory, personality and current condition, we can still treat oral history - as I mentioned above - as a source of various kinds of information. However, the quality and genre of information depends to a large extend on the question we ask during the interview. Being aware of other typologies in oral history I distinguish three types of questions about the information (informative function of questioning in oral history - see: above) that oral historian can ask, according to the subject of the answer: questions about (1) particular recollection (events, "pictures"), (2) data or (3) opinion. Each of them may be linked more with the present perspective (what I know and remember now), or more with the past perspective (what I knew and remembered then).

17 L. Adams, op. cit., p. 22.

18 That strategy of posing questions was proposed by Dariusz Jarosz at the $4^{\text {th }}$ Annual Workshop of Polish Oral History Association in November 2012 (Dom Spotkań z Historią, Warsaw). 
Asking about recollection (memoirs), about events, places and persons is the most common type of questioning and at the same time the most specific for oral history herself, regardless of the discipline that uses it (history, sociology, linguistic, anthropology etc.). According to Lynn Adams what differs oral history from all other kinds of qualitative research is the fact that oral history focuses on "the act of remembering the past" 19 . In many oral history interviews we ask mostly about particular events as seen from a personal perspective (what happened? how did it look like? who was there? etc.) and personal feelings from the past (how did you feel then? etc.). Sometimes recollection can be devoted not to an event, but to some permanent element of somebody's past that also became part of memory and its "images": e.g. appearance or character of somebody's friend, order of rooms in an old family house etc.

Questions about all kinds of data (the term is understood here in a broad sense) target at information from somebody's life scope gathered in autobiographical memory. If you ask: "how much did you earn when you began you job?", it will be a question about knowledge (data), not about memoirs. Questions about ancestors, parents' jobs etc. also refer to data we gathered in our memory through our life (in the past) and not to some "direct" (if one can say so) recollections. It does not mean that the answers to these questions are automatically less valuable; some data from the past we can remember pretty well and precisely, even if they are totally useless: a good example are old telephone numbers that stuck in our minds.

There is probably no sharp clear cut between asking about recollections from the past and data from the past. However, the researcher posing questions must be aware of the difference between them and know the different "affiliation" of the answers to both types in our individual memory. Events, "pictures" of places and personalities belong to our episodic memory, whereas all kinds of data are part of semantic memory. As we know from the psychological research we tend to forget how (in which context) we learned data from semantic memory or to mix many cognitive contexts into one . $^{20}$ "People will forget who said something, but will know what was

19 According to Lynn Adams what differs oral history form all other kinds of qualitative research is the fact that oral history focuses on "the act of remembering the past", L. Adams, op. cit., p. 2.

20 T. Maruszewski, Pamięć autobiograficzna, Gdańsk 2005, p. 50-69. 
said" - as nicely phrased it Józef Tischner ${ }^{21}$. Moreover, some of the data we keep in our memory may be biased and changed without our conscious reflection: we might be wrong and at the same time sure and convinced that we are right.

Finally we can ask about personal opinions, emotions etc. They can also be focused either on the past opinions (what did you think at that time?), or contemporary reflections about the past (what do you think about it today?), although - as we know - in practice contemporary perspective highly influences our opinions, even those from the past. By "opinion" I also understand all forms of personal explanations of the own biography, fates of own family, nation etc. "Why did you marry?", "Who was your best friend at that time?", "Why the communism collapsed?" - these are all examples of the questions about opinions. Asking about them is highly valuable if we seriously take into account human self-reflectiveness and let our interviewee construct his/her own interpretative schemes that are - according to well-known Alfred Schütz phenomenological terminology - "first-order constructs" of the actors of social life, i.e. their own interpretations and generalizations of their life experiences. It is probably useless to add that answers to the questions about opinions are the most subjective part of oral history. However, they allow us to build our research conclusions and interpretations: "constructs of the second degree"22. Only thanks to them we can understand how people explain to themselves the plot of their own life, their own decisions or changes that happened in their social worlds.

\section{Conversation analysis or the role of question in interpretation process}

If at the beginning I have complained about the questions being erased during the process of interpretation, here I would like to put an emphasis on their usefulness for the interpretation of oral history. According to above quoted Paul Thompson a researcher should have "the strategy of the interview", because than "questions can lead naturally from one to the other" 23 . However, in many cases the real interview goes differently than in

21 "Ludziska zabacują, fto pedzioł, ale wiedzóm, co pedzioł", J. Tischner, op. cit., p. 12.

22 A. Schütz, Collected Papers I: The Problem of Social Reality, Hague 1962, p. 6 et seqq.

23 P. Thompson, op. cit., p. 171. 
our initial plan. Our questions may not evoke the answers we might have expected and we cannot be sure who or what is to blame for that (if anything or anybody has to be blamed for that at all). Therefore in the process of interpretation of the oral history interview it is worthy to analyze the relationship between questions asked and answers given to them. Perspective of conversational analysis may deliver here a useful tool for that.

Sociology and other social sciences following the studies by Harold Garfinkel and Erving Goffman since 1960s has been elaborating theoretical perspective of conversational analysis (CA) developed by Harvey Sacks. It focuses on the observation of the sequences of verbal and non-verbal communication. Its goal is "to describe the intertwined construction of practices, actions, activities, and the overall structure of interactions" 24 . What differs CA from other perspectives (like discourse analysis) is an assumption that the social order is "orderly at a minute level of detail" 25 in the interaction and content of it is a result of an interplay between discussing persons' social definitions of situations. That perspective - very fruitful in research on the media communication or every-day-life talks - has naturally rather limited usage in oral history. Narrative interviews and life stories with small number of questions can be much better interpreted by various forms of qualitative sociology (Biographieforschung). However, in some types of oral history where sequences of dialogue are more frequent, benefits from using CA can be quite significant. Thanks to it we can tell something about the influence of the questions on the given answers.

Let me cite here one tiny example for that. In one of the hundreds interviews of the Oral History Archive of the Museum of Warsaw Uprising (www.ahm194.4.pl) we can find transcription of the dialogue between Halina Zofia Adamska (further: HZA, civilian 14-year-old girl living in Warsaw in 1944) and an interviewer Iwona Brandt (further: IB). In an excerpt of the interview we see the following sequences:

IB: Did you, as civilians living in Powiśle, have any contact with insurgents?

HZA: Yes, they have come to us, to sew stripes, bands for them.

IB: What precisely did you do?

24 J. Sidnell, T. Stivers, Introduction, [in:] The Handbook of Conversation Analysis, ed. by iidem, London 2012, p. 2.

25 Ibidem. 
HZA: I did not participate actively [i.e. as a soldier - M.J.] in the uprising. IB: But you did help?

HZA: I sewed stripes and uprising bonds together with our neighbors $[\ldots]^{26}$.

The interviewee understood question "what precisely did you do?" as a question, how she participated military in the uprising and therefore she stressed that she did not take "an active part" in it. She did not answer directly to the posed question, but rather to its meaning which she read through her looking-glass-self ("interviewer is interested in the history of the uprising, so she is asking me about the uprising"). That and the next question ("but you did help?") aim at finding proofs of Adamska's action and her contribution, therefore she feels obliged to find an answer that - in her opinion - may meet the expectations of the interviewer.

This example shows us that the informative content of oral history may not be only the result of simple recalling memories or answering questions, but also - among many reasons - the effect of dialogue itself and adjustment of the expectations of the two sides of it. That is why analyzing questions in oral history and their position in the dialogue sequences should be implemented in the in-deepen interpretation of oral history interviews. In my opinion, that can be taken (to certain degree) regardless of the methodological lenses through which we look at oral history and its position in historiography; whether we look for "facts", "data", "memory" or "experience". None of those perspectives can disregard the fact how (through which questions) we got the results that we use.

"IB: Czy wy jako cywile mieszkający na Powiślu, mieliście jakiś kontakt z powstańca$\mathrm{mi}$ ?

HZA: Owszem, przychodzili do nas, żeby im szyć naszywki, opaski.

IB: Co pani konkretnie robiła?

HZA: Czynnego udziału w Powstaniu nie brałam.

IB: Ale pomagała pani?

HZA: Szyłam łącznie z sąsiadkami naszywki i opaski powstańcze. [...]", Archiwum Historii Mówionej Muzeum Powstania Warszawskiego, the account of Halina Zofia Adamska recorded by Iwona Brandt on March 11, 2008, http://ahm.1944.pl/ Halina\%2oZofia_Adamska/1 (accessed December 5, 2015). 
All the above mentioned assumptions and arguments belong rather to the theory of oral history, instead of giving list of practical advices how to ask questions. However writing about oral history theory is impossible without mentioning practice, because oral history is first and foremost practice. Theory and practice of oral history are in the double-sided hermeneutical interrelation: "oral history practice then demands that one thinks about theory; indeed it is the practice, the doing of oral history that leads to theoretical innovation" 27 .

Therefore one have to bear in mind that in practice there are no ideal questions, as there are no ideal interviews. First, an interviewer who is well prepared for an interview has to have list of questions or issues that he or she wants to ask. However, not all of them have to be asked: a good interview do not always have to consist of many questions. Secondly, in many cases an interviewee will not answer to some of our smooth questions or will answer them in indirect way, saying something disconnected with the aim and topic of the question itself. Finally, only in the evaluation and analysis of the recorded material we can see the interrelation between our questions and the answers. Therefore, it is good to ask good questions, because they may give us good answers. But only analysis (like conversational analysis) of what we as researches have done, reveal that we ask questions not only to get answers, but also to build a basis for the whole relationship with and interviewee. 
Marcin Jarząbek

It is good to ask good questions - posing questions in oral history interview as a theoretical problem
The author discusses an issue of forming questions in oral history. There are two types of them - research questions and interview questions. Instead of analyzing how to ask questions, the interviewer should rather focus on why to ask them. The article proves that asking questions in oral history is less about formal elements such as what language should be used or what matters should be raised, but more about such elements as emotions or the overall atmosphere of an interview. The author gives some clues on how to prepare proper questions, what difficulties may appear and what to avoid in order to carry out a good interview. 